\title{
シロドシンの開発経緯
}

\author{
山崎芳伸
}

\section{Development of Silodosin}

\author{
Yoshinobu YAMAZAKI
}

Pharmacology Research Laboratory, R\&D, Kissei Pharmaceutical Co., Ltd., 4365-1 Kashiwabara, Hotaka, Azumino City 399-8304, Japan

前立腺肥大症（Benign prostatic hyperplasia：BPH） は中年層〜高年層の男性が罹患する疾患の 1 つで ある，正常な前立腺はクルミ大であるが，中高年以 降になると内腺に相当する部分に肥大がみられる ようになり，組織学的には 60 歳以上の男性の $50 \%$ 以上, 85 歳以上の約 $90 \%$ に前立腺の肥大が認められ ている.この前立腺の肥大による尿道の圧迫（下部 尿路閉塞）に，交感神経刺激を介寸る前立腺及び前 立腺部尿道の過剩収縮による閉塞が重なり，種々の 臨床症状が発現する。交感神経刺激を介する収縮は, 神経終末より放出された神経伝達物質のノルアド レナリンが，前立腺及び前立腺部尿道に豊富に存在 する $\alpha_{1}$-アドレナリン受容体に結合することにより 誘発される。

BPH による臨床症状には，下部尿路閉塞に起因す る排尿症状と，膀胱機能異常に起因する蓄尿症状が ある. BPH の診断に最も普遍的に用いられている WHO（世界保健機構）により 1995 年に制定された I-PSS (International Prostate Symptom Score : 国際前 立腺症状スコア) では, 排尿症状としては尿線途絶, 尿勢低下, 腹圧排尿が, 蓄尿症状としては昼閒頻尿, 夜間頻尿，尿意切迫感が，排尿後症状としては残尿 感が上げられている．また，本邦にて 2001 年に発 行された「EBM に基づく前立腺肥大症診療ガイド ライン」をみると，BPH に対する治療方針には，無 治療経過観察, 薬物療法, 低侵襲治療（手術），外 科的治療及び尿道留置カテーテルなどが選択され

キッセイ薬品工業株式会社 薬理研究所 e-mail: yoshinobu_yamazaki@pharm.kissei.co.jp
ており, 薬物療法は主に全般重症度が軽症から中等 症が適応とされている.

現在, 薬物療法には $\alpha_{1}$ 遮断薬, 抗男性ホルモン 薬, 漢方薬, 植物製剤などが用いられているが，効 力, 使い易さなどからファーストチョイスとされて いるのは $\alpha_{1}$ 遮断薬である. 1970 年代に行われたフ エノキシベンザミン（非選択的 $\alpha$ 遮断薬）を用いた 臨床研究に端を発して, 前立腺及び尿道平滑筋の緊 張（収縮）が下部尿路閉塞を引き起こすこと, さら には之の下部尿路平滑筋の収縮は $\alpha_{1}$ 受容体を介す ることが明らかとなり, BPH に伴う排尿障害の治療 薬として塩酸プラゾシン, 塩酸テラゾシン等の $\alpha_{1}$ 遮断薬が使用されるようになった。しかしながら， これら治療薬は元来降圧剤として用いられていた 薬剂であり，起立性低血圧やめまいなどが副作用と して問題となっていた. その後， $\alpha_{1}$ 受容体にサブタ イプの存在が報告され, 分子生物学的手法を用いた 検討も加わり，現在 $\alpha_{1}$ 受容体は $\alpha_{1 \mathrm{~A}}, \alpha_{1 \mathrm{~B}}$ 及び $\alpha_{1 \mathrm{D}}$ の3 種類のサブタイプに分類されている. ヒトの各 種臟器に存在する $\alpha_{1}$ 受容体の分布に関する研究も 進み, BPH 患者の前立腺や男性尿道には主に $\alpha_{1 \mathrm{~A}}$ 受容体が分布していることが明らかとなった。一方, 血圧調節に関与している血管系（特に高齢者）では $\alpha_{1 \mathrm{~B}}$ 受容体が多く分布すると考えられている。塩酸 プラゾシン及び塩酸テラゾシンによる血圧低下は, これらの薬剤の $\alpha_{1}$ 受容体各サブタイプに対する親 和性にほとんど差がないことに起因すると考えら れ, 排尿障害の治療薬には $\alpha_{1 \mathrm{~A}}$ 受容体に選択性の高 い薬剂が有用となると考えられた。

ついで，高血圧症の適応を持たない排尿障害治療 
薬として開発されたのが塩酸タムスロシンやナフ トピジルであり, 従来の $\alpha_{1}$ 遮断薬に比べて比較的 下部尿路選択性に優れ，血圧低下作用の少ない治療 薬として現在繁用されている。これらの薬剤の登場 により副作用の軽減は図られたように思われた。一 方で，比較的自覚症状が重い場合には $\alpha_{1}$ 遮断薬は 有効性が十分でないとの報告もあり，有効性のみを 高めることができれば軽症から重症まで幅広く用 いることが可能となり， $\alpha_{1}$ 遮断薬による治療の幅を 広汭ことが可能となると考えられた。

キッセイ薬品工業株式会社では, 1990 年代初頭に, 血圧に影響を及ぼさない，下部尿路選択性の高い $\alpha_{1}$ 遮断薬の創製を目指したプロジェクトが発足し た. 従来のキナゾリン系若しくはフェニルピペラジ ン系の $\alpha_{1}$ 遮断薬は $\alpha_{1 \mathrm{~A}}$ 受容体に対する選択性が之 しいため, インドリン骨格をもとに，カルバモイル 基及びトリフルオロエトキシ基を導入して，作用持 続性と $\alpha_{1 \mathrm{~A}}$ 受容体選択性を高めるように化合物合 成を計画した，そして，摘出動物前立腺・血管標本 を用いた評価, 並びに生体位動物の下部尿路機能及 び血圧に対する評価を経て, 下部尿路選択的な新規 インドリン誘導体シロドシン（開発コード名：

KMD-3213）を見出した（Fig. 1）.

続いてシロドシンの $\alpha_{1}$ 受容体サブタイプに対す る親和性を検討したところ， $\alpha_{1 \mathrm{~B}}$ 及び $\alpha_{1 \mathrm{D}}$ 受容体に 比し $\alpha_{1 \mathrm{~A}}$ 受容体に極めて高い選択性を有すること
が判明した。よって，下部尿路及び血管を用いた評 価にて見出されたシロドシンの下部尿路選択性の 高さは, その $\alpha_{1 \mathrm{~A}}$ 受容体に対する選択性の高さに起 因することが明らかとなった，その後，本邦におい てシロドシンの臨床開発が進められ（第而相臨床試 験より第一製薬株式会社と共同開発），有効性及び 安全性が検証されたことより BPH に伴う排尿障害 の治療薬として承認申請に至った。 今回は, 以下に シロドシンの非臨床薬理, 薬物動態及び毒性試験の 結果並びに臨床薬物動態試験成績を紹介する。なお， シロドシンは現在, ヨーロッパ, アメリカ, 中国及 び韓国において臨床開発が進行中である.

厚生労働省の患者調査によると, 本邦の BPH 患 者は人口の高齢化に伴い増加しており, 潜在患者も 含めるとその数は今後も増加の一途をたどると思 われる.このように増加を続ける BPH 患者に対し, シロドシンがその薬物療法の一助となることを期 待したい.

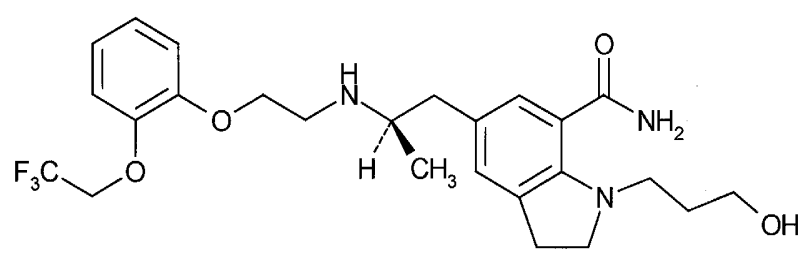

Fig. 1. Chemical Structure of Silodosin 